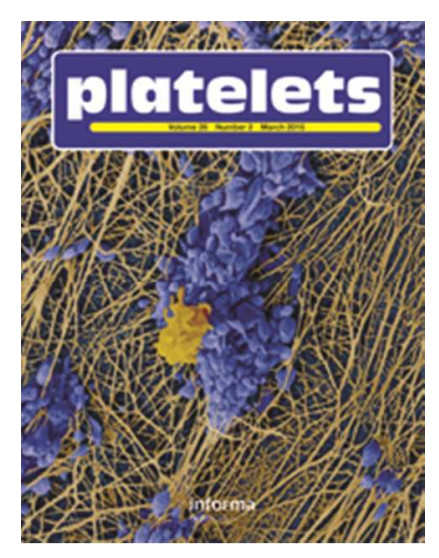

\title{
Antimicrobial properties of Platelet-rich preparations. A systematic review of the current pre-clinical evidence
}

\begin{tabular}{|r|l|}
\hline Journal: & Platelets \\
\hline Manuscript ID & CPLA-2015-0202.R3 \\
\hline Danuscript Type: & Review \\
\hline Complete List of Authors: & $\begin{array}{l}\text { Del Fabbro, Massimo; Scientific Institute for Care and Clinical Research } \\
\text { (IRCCS) Galeazzi Orthopedic Institute, Department of Biomedical, Surgical } \\
\text { and Dental Sciences, } \\
\text { Bortolin, Monica; IRCCS Galeazzi Orthopedic Institute, } \\
\text { Taschieri, Silvio; IRCCS Galeazzi Orthopedic Institute, ; Università degli } \\
\text { Studi di Milano, } \\
\text { Ceci, Caterina; IRCCS Galeazzi Orthopedic Institute, ; Università degli } \\
\text { Studi di Milano, } \\
\text { Weinstein, Roberto; IRCCS Galeazzi Orthopedic Institute, ; Università degli } \\
\text { Studi di Milano, }\end{array}$ \\
\hline Keywords: & $\begin{array}{l}\text { antimicrobial activity, platelet concentrates, systematic review, platelet rich } \\
\text { plasma }\end{array}$ \\
\hline \multicolumn{2}{|c}{} \\
\hline
\end{tabular}




\author{
Antimicrobial properties of Platelet-rich preparations. A systematic review of the current pre- \\ clinical evidence. \\ Massimo Del Fabbro, BSc, $\mathrm{PhD}^{1,2}$, Monica Bortolin, BSc, $\mathrm{PhD}^{2}$, Silvio Taschieri, MD, DDS ${ }^{1,2}$, \\ Caterina Ceci, BSc ${ }^{1,2}$, Roberto L. Weinstein, $\mathrm{MD}, \mathrm{DDS}^{1,2}$ \\ 1 Dipartimento di Scienze Biomediche, Chirurgiche e Odontoiatriche, Università degli Studi di \\ Milano, Milano, Italy. \\ 2 IRCCS Istituto Ortopedico Galeazzi, Milano, Italy.
}

Short title: Do platelet concentrates help fighting infections?

Corresponding Author:

Prof. Massimo Del Fabbro

Università degli Studi di Milano

IRCCS Istituto Ortopedico Galeazzi

Via Riccardo Galeazzi 4, 20161, Milano, Italy

Tel. +390250319950

Fax +390250319960

Email: massimo.delfabbro@,unimi.it 


\begin{abstract}
In recent years autologous platelet concentrates (APC) became popular in several medicine fields, representing a valuable adjunct to regenerative surgical procedures. Beneficial effects in the control of postsurgical discomfort and infection have also been frequently reported, suggesting that APC may possess anti-inflammatory and antimicrobial properties. Aim of the present review was to summarize the current evidence regarding antimicrobial effects of platelet concentrates, investigated by in vitro and animal studies. This review was conducted following a systematic approach. An electronic search was performed on MEDLINE, EMBASE and Scopus databases using appropriate search terms, without language or time restrictions. Preclinical studies assessing the antimicrobial activity of APC were included and divided according to the experimental design. Twenty in vitro studies and four animal studies, investigating APC effects on a broad range of microorganisms, were included. In in vitro studies APC reduced the growth of microorganisms during the first hours of incubation, while they could not completely break down the microbial load. In fact, over time a recovery of bacterial growth was always observed, suggesting that APC display a bacteriostatic rather than a microbicidal activity. All animal studies showed that APC administered by local injections were able to reduce the infection caused by different microorganisms, although to a lesser extent compared to antibiotics. In conclusion, though the exact action mechanisms of interaction with microbial pathogens need further investigation, platelet concentrates proved to have antimicrobial properties, and therefore could represent a useful natural substance for controlling postoperative infections at surgical sites.
\end{abstract}




\section{Introduction}

During the past 20 years, autologous platelet-rich preparations have achieved a great popularity in various fields of medicine such as dentistry, oral surgery, orthopedics, sports medicine, dermatology, ophthalmology, cosmetic and plastic surgery [1-3]. The rationale for their use is the release of growth factors and other bioactive molecules, stored in intracellular $\alpha$-granules and released upon platelet activation that help to modulate wound healing in both hard and soft tissues. In addition, anti-inflammatory and antimicrobial properties of platelet-rich preparations have been recently pointed out [4-6].

While the regenerative potential of platelet concentrates has been extensively explored since their introduction in regenerative medicine in the oral and maxillofacial surgery field during the late '90s [7-8], only few studies have investigated their antimicrobial effect, although an increase of publications in this field of research occurred in recent years.

The mechanisms underlying the antimicrobial effect of platelet concentrates are not yet clear. Platelet concentrates consist of a complex mixture of variable concentrations of platelets and plasma and, depending upon the protocol used for their production, variable content of leukocytes, embedded in a more or less dense fibrin matrix [2,9-10]. Nevertheless, the respective impact and mechanism of action of each component, as well as possible synergistic effects among these components, in the fight against infection are poorly known.

The first studies hypothesizing the antimicrobial activity of platelets date back several decades [1112]. Platelets act as sentinels of vascular system, express a wide range of potential bacterial receptors, may have the ability to internalize bacteria and are able to release a broad variety of molecules that provide an array of host defense functions [13]. Subsequently, several attempts took place in order to isolate and characterize specific antimicrobial molecules from platelets of human and animal origin [14-19]. In vitro studies demonstrated that platelets, following stimulation with thrombin, are able to release proteins with antimicrobial activity against bacteria and fungi [17-18]. In addition to the release of antimicrobial peptides, platelets are also able to generate reactive 
oxygen species, bind and internalize microorganisms and participate in antibody-dependent cellular cytotoxicity [20]. Recent studies underlined the direct role of platelets in recognize, sequester and neutralize invading pathogens, as well as their indirect contribution to recruit leukocytes to infection and inflammation sites, and to modulate their behavior, enhancing their ability to phagocytose and kill microorganisms by triggering different types of signaling pathways [21].

The role of leukocytes in platelet concentrates is subject of an intense debate. According to some authors, an increase in the concentration of white blood cells into platelet concentrates could help to improve the stability of the scaffold, increase the antimicrobial potential and regulate the inflammatory response $[10,22]$. On the contrary, other authors recommend excluding leukocytes from platelet concentrates, as these cells might lead to an increase of the inflammatory response due to the secretion of acid hydrolases, metalloproteases and other pro-inflammatory proteases [1,9].

The aim of this review was to collect and summarize the available preclinical evidence regarding the antimicrobial efficacy of platelet concentrates, in order to shed light upon their underlying mechanisms and potential benefits.

\section{Materials and methods}

\section{Literature search}

A search was performed by two authors (MDF, MB) on electronic databases (MEDLINE, EMBASE, Scopus), using the following search terms, alone and in combination, by means of Boolean operators: "platelet-rich plasma", "platelet concentrate", "platelet-rich fibrin", "platelet growth factors", "microorganisms", "bacteria", "antibacterial”, "antimicrobial” and "infection". No language nor time restrictions were applied. The last electronic search was performed on October 2015. Reference lists of the reviews and of the identified articles were also checked for possible additional studies. Finally, the manufacturing companies producing devices for concentrating platelets were contacted to identify ongoing or unpublished studies pertinent to this review.

\section{Inclusion and exclusion criteria}


Preclinical studies (including animal and in vitro studies) assessing the antimicrobial activity of platelet concentrates were included. All other types of study design were excluded.

\section{Data extraction}

The titles and abstracts of the retrieved articles were independently screened by two reviewers (MB, MDF) and studies meeting the inclusion criteria were identified. When the title and abstract of an article did not provide sufficient information to make a decision, the full text was obtained and examined. Publications that did not meet the inclusion criteria were excluded. The full text of the included studies was obtained for data extraction and quality assessment. The characteristics of the selected studies were examined and the articles were sorted into two groups: (a) in vitro studies; (b) animal studies.

\section{Assessment of the risk of bias}

The risk of bias of the included studies was evaluated independently and in duplicate by two reviewers $(\mathrm{MB}, \mathrm{CC})$ as part of the data extraction process. In vitro included manuscripts were assessed considering the CRIS Guidelines, specifically developed for improving the quality of reporting of in vitro studies in experimental research [23]. The following criteria were considered: sample size calculation; meaningful difference between groups (comparability of control and treatment groups at entry); sample preparation and handling; randomization method; concealment of sequence allocation; blinding of operator(s) and evaluator(s); conflict of interest statement; statistical analysis. The assessment of animal studies was conducted considering criteria adapted from the ARRIVE guidelines [24] specifically developed for rating the quality of animal studies. The criteria considered were: experimental animals (species, age, weight); sample size calculation; ethical statement; randomization method; concealed allocation of animals to experimental group; blinding of operator(s) and evaluator(s); conflict of interest statement. All these criteria were judged as adequate (yes), unclear or non adequate (no). In order to summarize the validity of studies, they were grouped into the following categories: A) Low risk of bias if none of the quality criteria was judged as inadequate and no more than two of them were judged as unclear; B) Moderate risk of 
bias if 1 to 3 criteria was judged as inadequate; C) High risk of bias if four or more criteria were judged as inadequate. In case of discrepancy between the two reviewers, an agreement had to be obtained by discussion. Otherwise, a third reviewer was consulted (ST) until consensus was achieved by discussion. The risk of bias assessment results were synthesized using the software RevMan (Review Manager Version 5.3, 2014; The Nordic Cochrane Center, The Cochrane Collaboration, Copenhagen, Denmark).

\section{Results}

The initial electronic search provided 188 articles. Figure 1 is a flowchart that summarizes the article selection process. After screening of the titles and abstracts, 34 studies evaluating the antimicrobial effect of platelet concentrates were identified. No further study was identified by other search methods. After review of the full text, ten publications were excluded for the following reasons. In three studies, antimicrobial peptides extracted from platelets were used instead of platelet concentrates [17-19]; four articles reported on clinical studies [25-28]. One publication was a review and the other two were letters to the editor $[5,29,58]$. Twenty-four articles fulfilled inclusion criteria and were finally included in the present analysis [6,30-52]. Twenty were in vitro studies and four were animal studies. The included articles were published in a period ranging from 2007 to 2015. The articles adopted a broad range of variable outcomes and evaluated a number of microorganisms for assessing the antimicrobial potential of platelet concentrates.

In vitro studies

In vitro studies evaluating the antimicrobial activity of platelet concentrates are listed in Table I. The experimental design varied considerably among studies. Several types of bacteria were tested, both Gram-positive (e.g. Streptococci and Staphylococci) and Gram-negative (e.g. Escherichia coli, Pseudomonas aeruginosa) strains, obtained from the American Type Culture Collection (ATCC) or isolated from clinical samples, and characterized by a different susceptibility to antibiotics (e.g. MRSA and MSSA, that is methicillin-resistant and methicillin-susceptible Staphylococcus aureus, 
respectively). In one study, a yeast strain (Candida albicans) was also tested [39]. Different tests were performed in order to assess the antimicrobial activity of autologous platelet concentrates (APC), such as killing curves, Kirby-Bauer disc-diffusion method or determination of the minimum inhibitory concentration. Furthermore, various methods were used for the preparation of platelet concentrates themselves, then platelet and leukocyte content was variable among studies (Table 1). According to the classification proposed by Dohan Ehrenfest et al. [10], nine studies used leukocyte- and platelet-rich plasma (L-PRP), while eight studies used pure platelet-rich plasma ( $\mathrm{P}$ PRP) and three studies used both formulations. Platelets were activated by adding calcium chloride, thrombin (either bovine or autologous) or a mixture of the two. Moreover, in one study a comparison between activated and non-activated P-PRP was made [46]. In some studies, platelet concentrates were subjected to procedures different from the standard protocols recommended by the manufacturers of the devices for obtaining autologous platelet concentrates, in order to better understand which component in APC is the responsible for the antimicrobial activity. In the study of Edelbute et al. PRP was centrifuged to separate the clot from the supernatant [43]. In the study of Rozalski et al. platelets were lysed by repeated freezing/thawing cycles and stimulated with ADP [37], while in the study of Burnouf et al. PRP was subjected to a treatment based on the use of specific solvents and detergents [41]. Mariani et al. [52] froze PRP to assess whether the preparation maintained in vitro characteristics, observing that PRP may be cryopreserved without important changes to its effectiveness. The blood source from which platelet concentrates were prepared varied among studies (human or animal origin).

As regards study findings, in general it was observed a tendency of platelet concentrates to inhibit the growth of microorganisms during the first hours of incubation, while they did not seem to be able to break down completely the microbial load: after an initial reduction of the inoculum, in fact, a recovery of bacterial growth was always observed, indicating that platelet concentrates displayed an inhibitory (bacteriostatic) rather than a microbicidal activity. Concerning single bacterial species, S. aureus was the most tested microorganism and always showed susceptibility to platelet 
concentrates, while Escherichia coli, Pseudomonas aeruginosa, Enterococcus faecalis and Klebsiella pneumoniae were less frequently adopted and produced contradictory results: in some studies antimicrobial activity was observed, but in others no inhibitory effect against these species was obtained In addition, some species were tested only once (e.g. Bacillus megaterium, Propionibacterium acnes, Proteus mirabilis, Fusobacterium nucleatum, etc.) showing an antibacterial activity. Regarding quality assessment, all in vitro studies were classified at high risk of bias as in all cases more than four criteria were judged as inadequate. In general the sample preparation and handling was always well described, the statistical analysis was mostly appropriate, but no details were provided regarding sample size calculation, randomization procedures, allocation concealment and blinding, which may rise some concern on the validity of the results.

\section{Animal studies}

Four preclinical studies were carried out using the rabbit as animal model, the L-PRP as platelet concentrate and the $S$. aureus as tested microorganism (Table II). In particular, one study used a model of spinal implant-associated infection [50], while the other studies adopted a model of osteomyelitis [48-49,51].

The study bi Li et al. on implant-associated infection, which also included an in vitro evaluation, interestingly found that the antimicrobial properties of PRP are positively related to the concentration of thrombin used for PRP activation [50]. While surgical non-infected sites were clear of infection at all time points studied (1, 2 and 3 weeks), the surgical sites with bacterial challenge displayed elevated bumps, that were relatively smaller for sites treated with PRP respect to infected control sites. Significant amount of pus was present in all experimentally infected sites [50]. Postmortem quantification of bacteria in surgical sites showed that PRP treatment sites had significantly fewer bacterial colonies in bone samples than infected control sites at all time points studied, suggesting that PRP may be a useful adjunct strategy against post-operative implantassociated infections [50]. 
In the other three in vivo studies osteomyelitis was induced in rabbits according to a standard protocol: a hole was drilled in the cortex of the right proximal tibia metaphysis using a $2.0 \mathrm{~mm}$ Kirschner wire and an 18-gauge needle was inserted into the medullary cavity, which was subsequently irrigated with saline after bone marrow extraction. Then, a solution containing a bacterial suspension was injected into the medullary cavity. In the test group, additional injection of platelet concentrate into the medullary cavity was performed. The effect of platelet concentrates was evaluated radiographically and histologically [48-49,51]. All the studies regarding osteomyelitis showed that L-PRP administered to animals by local injections was able to reduce the infection caused by both MRSA and MSSA, although to a lesser extent compared to antibiotics, as well as to accelerate bone regeneration [48-49,51].

Regarding quality assessment, two studies were classified at high risk of bias as four or more criteria were judged as inadequate $[48,50]$ and two studies were judged at moderate risk of bias $[49,51]$.

\section{Discussion}

The regenerative properties of platelet concentrates have been considerably investigated during the last two decades. On the contrary, in literature only few reports were found about their antimicrobial potential.

The aim of this work was to collect the available pre-clinical evidence, consisting of in vitro and animal studies evaluating the antibacterial efficacy of autologous platelet concentrates. The results of in vitro studies suggest that platelet concentrates may effectively inhibit the growth of a wide variety of microorganisms. However, when considering specific bacterial species, results were sometimes contradictory. For example, Bielecki et al. [30] reported no activity of PRP against $E$. faecalis, while four other studies found an inhibitory effect against the same microorganism $[17,33,39,46]$. Similarly, some authors reported the efficacy of platelet concentrates against $P$. aeruginosa $[6,8,13,15,17]$ while other researchers indicated no antimicrobial activity $[29,31,38]$. 
Such discrepancies could be due to several reasons such as the intrinsic characteristics of the bacterial strains used, which may display a different susceptibility to platelet concentrates per se or to the different sensitivity of the test used for assessing the antibacterial activity. Other important reasons for explaining the observed variability in outcomes could be ascribed to the types of platelet concentrates used that, as also explained later, may differ in form (gel or liquid), as well as in the concentration of platelets, content of leukocytes, density of the fibrin network, the activation mode that may occur naturally by contact with tissues or may be induced by thrombin or calcium chloride adjunct, and the administration mode in vivo that may be topical or by injection. Though the results provided by the in vitro studies analyzed in the present review are certainly suggestive for a significant antimicrobial potential of platelet-rich preparations, when analyzing the quality of these studies some concern emerged. The advantages of in vitro studies as compared to a clinical trial include the possibility of control over independent variables and unforeseen bias and the precision of all operative steps. This should improve the internal validity of the results. However, one of the major drawbacks is that in vitro studies lack external validity and generalizability to clinical reality. Though in vitro studies are relatively simpler to perform, they may lack certain methodological rigor that characterize well-conducted clinical trials. In the present review the quality of in vitro studies was assessed according to established guidelines specifically developed for experimental lab research [23]. The results, however, indicate that only a few studies demonstrated a sufficient methodological rigor and the overall quality is to be considered poor. Therefore, the findings of the review should be interpreted cautiously and need to be confirmed by further studies, which should be conducted and reported in conformity to the above mentioned guidelines. Existing shortcomings among in vitro studies, that need to be addressed to promote quality and transparency of evidence, could include the reporting of all methodological details enabling the reader/researcher to analyze and understand the variability affecting the outcome measure of experimental procedures, materials, techniques under investigation. In particular, considering the results of the quality assessment, more details should be provided regarding sample size calculation, randomization methods, allocation 
concealment, blinding of operators and evaluators, and clear definition of a meaningful difference among groups, as may be evinced from Fig. 2a.

The evidence of the in vivo antimicrobial effectiveness of platelet concentrates is still scarce. As regards animal studies considered in the present review, very few papers have been found investigating the antimicrobial efficacy of platelet concentrates. However, in two different experimental models of infection in rabbits a positive effect of PRP was evidenced. The experimental observations suggested that PRP might represent a novel strategy to prevent bone infections, thanks to its ability to stimulating bone regeneration together with the ability of controlling microbial growth and spreading. The quality assessment of the in vivo studies yielded better results as compared to the in vitro studies as only two in vivo studies were judged at high risk of bias and two at moderate risk of bias. The interesting results emerged from the animal studies need to be validated by clinical evidence. As regards human studies, some retrospective comparative investigations showed that the incidence of both superficial and deep sternal wound infection in patients undergoing cardiac surgery was significantly lower for the wounds treated with platelet gel at the time of surgical wound incision compared with untreated controls [25-26]. These studies reported that the application of platelet gel also contributed to decreasing the postoperative blood loss and the length of hospital stay and costs for the treated patients. In addition, platelet gel proved to be effective in the treatment of an infected deep cutaneous wound [27], a deep sternal wound infection developed after cardiac surgery [28], and in a case of chronic femoral osteomyelitis [53].

Though the role of platelets as effective modulators and effectors of the immune response emerged in the recent years, to date, the components responsible for the antimicrobial activity of platelet concentrates remain poorly understood, in particular because these biomaterials are a complex mixture of variable proportions of platelets, white blood cells and plasma. The observation that blood plasma contains substances acting against microbes dated back more than 100 years ago [54]. At the base of the antimicrobial properties of plasma is the presence of the complement, an element 
of the immune system essential for the mechanisms of humoral defense against infectious agents. The activation of the complement cascade determines bacterial cell lysis and leukocyte recruitment. A recent in vitro study showed that, after heat inactivation, PRP lost its inhibitory effect against $E$. coli, Klebsiella pneumoniae and P. aeruginosa [41]. Another study showed that platelets isolated from plasmatic components were not able to inhibit the growth of Enteroccoccus faecalis, Streptococcus agalactiae, Streptococcus oralis and S. aureus [46]. Taken together, these data seem to suggest that some plasmatic components (such as the complement) are mainly responsible for the antimicrobial activity of platelet concentrates, and that a cooperation between platelets and plasmatic elements is necessary. The respective impact of the plasma and cellular components has not yet been studied in detail, though, as discussed below, some studies reported that in the absence of plasma the antimicrobial potential of platelets alone is negligible, suggesting that there is a synergistic effect among different components of platelet concentrates [46]. Several platelet receptors have been demonstrated to interact with a number of pathogens either directly or indirectly, suggesting a plasma protein interplay that may be crucial in the early immune defense [55-56]. On the other hand, many studies have shown that different bacterial species may interact with platelets, modulating their function and activation, in a strain- and subject-dependent manner, through different mechanisms [57]. Hence, there seems to be a two-way interaction between platelets and bacterial pathogens, that may result in complete or incomplete activation, or even inhibition of platelet activation, in function of the bacterial species and bacterial secreted product involved, which may ultimately affect the cellular soluble immune response [55-56].

Several techniques are available for the production of platelet concentrates, leading to products with different biological characteristics. According to Dohan Ehrenfest et al., the various platelet concentrates can be classified into four main categories, depending on their leukocyte and fibrin content: P-PRP, L-PRP, pure platelet-rich fibrin (P-PRF) and leukocyte- and platelet-rich fibrin (LPRF) [10]. L-PRP and L-PRF might contain substantial amount of white blood cells. The contribution of leukocytes to the observed overall effect remains unclear. As concerns the 
antimicrobial effect, white blood cells play undoubtedly a fundamental role in vivo: leukocytes, particularly neutrophils, represent the first line of defense against invading microorganisms. White blood cells possess a phagocytic activity and constitute a rich source of antimicrobial molecules (e.g. defensins, cathelicidins, lysozyme, myeloperoxidase). However, it is unknown how they can perform their function after they are removed from the circulation for the preparation of platelet concentrates and applied directly to the surgical site, bypassing the physiological stage of migration. What emerged from this review is that, to date, only a few studies compared platelet concentrates poor and rich in leukocytes $[6,44,52]$ and all seem to suggest that there are no substantial differences between the antimicrobial activity of the two formulations. However, no definitive conclusions can be drawn on the base of only two studies, and further comparative studies are needed in order to clarify the role of leukocytes within APC.

Among the limitations of the present review there is the heterogeneity among the study aims, materials and protocols, the overall limited number of microbial species investigated, the limited characterization of platelet concentrates used (the cell composition, the concentration of the various growth factors and molecules possibly involved in the antimicrobial action was not routinely assessed). Though all the studies considered in the present review showed to a various extent that platelet concentrates have antimicrobial potential, the great diversity in the experimental design makes difficult to perform comparisons among the different studies. A greater standardization is needed in order to draw conclusions with a sufficient level of evidence.

\section{Conclusions and future research}

In addition to the well-established regenerative properties, platelet concentrates seem to possess also antimicrobial properties, and therefore could represent a useful substance for fighting postoperative infections of surgical sites. Infections are among the most serious complications that can affect the healing of a wound. Even when applying a strict disinfection protocol, bacteria can find a pathway to infiltrate and colonize the underlying tissues. The subsequent release of 
proteolytic enzymes and bacterial toxins-rich exudates, and the consequent chronic inflammation, can seriously affect healing. The increase of antibiotic-resistant bacteria has led the medical community to look for new treatments for infections. The development of alternative strategies, such as autologous platelet concentrates, which could reduce the incidence of post-operative infections and consequently the length of hospitalization, could have a considerable socio-economic impact. Future research should be focused on the determination of the exact antimicrobial spectrum, of the role played by the various components of platelet concentrates, and of the influence of patient characteristics (e.g. age, sex, blood parameters, drug assumption, etc.) on the antimicrobial properties. It would be also interesting to combine platelet concentrates with conventional techniques used for the treatment of infections (e.g. antibiotics), in order to assess the presence of a possible synergistic effect, and to investigate more deeply the in vivo antimicrobial efficacy in the various fields of medicine.

\section{Declaration of interest}

The authors declare that they have no conflicts of interest. 


\section{References}

[1] Anitua E, Sanchez M, Orive G, Andia I. The potential impact of the preparation rich in growth factors (PRGF) in different medical fields. Biomaterials 2007;28:4551-4560.

[2] Anitua E, Sánchez M, Orive G. Potential of endogenous regenerative technology for in situ regenerative medicine. Adv Drug Deliv Rev 2010;62:741-752.

[3] Bielecki T, Dohan Ehrenfest DM. Platelet-rich plasma (PRP) and Platelet-Rich Fibrin (PRF): surgical adjuvants, preparations for in situ regenerative medicine and tools for tissue engineering. Curr Pharm Biotechnol 2012;13:1121-1130.

[4] El-Sharkawy H, Kantarci A, Deady J, Hasturk H, Liu H, Alshahat M, van Dyke TE. Plateletrich plasma: growth factors and pro- and anti-inflammatory properties. J Periodontol 2007;78:661-669.

[5] Cieslik-Bielecka A, Dohan Ehrenfest DM, Lubkowska A, Bielecki T. Microbicidal properties of Leukocyte- and Platelet-Rich Plasma/Fibrin (L-PRP/L-PRF): new perspectives. J Biol Regul Homeost Agents 2012;26(Suppl 1):43S-52S.

[6] Anitua E, Alonso R, Girbau C, Aguirre JJ, Murozabal F, Orive G. Antibacterial effect of plasma rich in growth factors (PRGF-Endoret) against Staphylococcus aureus and Staphylococcus epidermidis strains. Clin Exp Dermatol 2012;37:652-657.

[7] Marx RE, Carlson ER, Eichstaedt RM, Schimmele SR, Strauss JE, Georgeff KR. Plateletrich plasma: Growth factor enhancement for bone grafts. Oral Surg Oral Med Oral Pathol Oral Radiol Endod 1998;85:638-646.

[8] Anitua E. Plasma rich in growth factors: preliminary results of use in the preparation of future sites for implants. Int J Oral Maxillofac Implants 1999;14:529-535.

[9] Anitua E, Andia I, Ardanza B,Nurden P,Nurden AT. Autologous platelets as a source of proteins for healing and tissue regeneration. Thromb Haemost 2004;91:4-15.

[10] Dohan Ehrenfest DM, Rasmusson L, Albrektsson T. Classification of platelet concentrates: from pure platelet-rich plasma (P-PRP) to leukocyte- and platelet-rich fibrin (L-PRF). Trends 
Biotechnol 2009;27:158-167.

[11] Hirsch JG. Comparative bactericidal activities of blood serum and plasma serum. J Exp Med 1960;112:15-22.

[12] Wecksler BB, Nachman RL. Rabbit platelet bactericidal protein. J Exp Med $1971 ; 134: 1114-1130$.

[13] Hamzeh-Cognasse H, Damien P, Chabert A, Pozzetto B, Cognasse F, Garraud O. Platelets and infections - complex interactions with bacteria. Front Immunol 2015;6:82. doi: 10.3389/fimmu.2015.00082.

[14] Yeaman MR, Norman DC, Bayer AS. Staphylococcus aureus susceptibility to thrombininduced platelet microbicidal protein is independent of platelet adherence and aggregation in vitro. Infect Immun 1992;60:2368-2374.

[15] Yeaman MR, Puentes SM, Norman DC, Bayer AS. Partial characterization and staphylocidal activity of thrombin-induced platelet microbicidal protein. Infect Immun 1992;60:1202-1209.

[16] Yeaman MR, Ibrahim AS, Edwards JE Jr, Bayer AS, Ghannoum MA. Thrombin-induced rabbit platelet microbicidal protein is fungicidal in vitro. Antimicrob Agents Chemother $1993 ; 37: 546-553$.

[17] Yeaman MR, Tang YQ, Shen AJ, Bayer AS, Selsted ME. Purification and in vitro activities of rabbit platelet microbicidal proteins. Infect Immun 1997;65:1023-1031.

[18] Krijgsveld J, Zaat SA, Meeldijk J, van Veelen PA, Fang G, Poolman B, Brandt E, Ehlert JE, Kuijpers AJ, Engbers GH, Feijen J, Dankert J. Thrombocidines, microbicidal proteins from human blood platelets, are C-terminal deletion products of CXC chemokines. J Biol Chem 2000;275:20374-20381.

[19] Tang YQ, Yeaman MR, Selsted ME. Antimicrobial peptides from human platelets. Infect Immun 2002;70:6524-6533.

[20] Yeaman MR. The role of platelets in antimicrobial host defense. Clin Infect Dis 1997, 
25:951-968.

[21] Jenne CN, Kubes P. Platelets in inflammation and infection. Platelets 2015;26:286-292.

[22] Ríos DL, López C, Carmona JU. Platelet-rich gel supernatants stimulate the release of antiinflammatory proteins on culture media of normal equine synovial membrane explants. Vet Med Int 2015;2015:547052.

[23] Krithikadatta J, Gopikrishna V, Datta M. CRIS Guidelines (Checklist for Reporting Invitro Studies): A concept note on the need for standardized guidelines for improving quality and transparency in reporting in-vitro studies in experimental dental research. J Conserv Dent 2014;17:301-304.

[24] Kilkenny C, Browne WJ, Cuthill IC, Emerson M, Altman DG. Improving Bioscience Research Reporting: The ARRIVE Guidelines for Reporting Animal Research. PLoS Biol 2010;8(6): e1000412. doi:10.1371/journal.pbio.1000412

[25] Trowbridge CC, Stammers AH, Woods E, Yen BR, Klayman M, Gilbert C. Use of platelet gel and its effects on infection in cardiac surgery. J Extra Corpor Technol 2005;37:381-386.

[26] Englert SJ, Estep TH, Ellis-Stoll CC. Postoperative surgical chest and leg incision sites using platelet gel: a retrospective study. J Extra Corpor Technol 2008;40:225-228.

[27] Cieslik-Bielecka A, Bielecki T, Gazdzik TS, Arendt J, Krol W, Szczepanski T. Autologous platelets and leukocytes can improve healing of infected high-energy soft tissue injury. Transfus Apher Sci 2009;41:9-12.

[28] Kachel E, Callum J, Moussa F, Goldstein J, Fremes S. Treatment of deep sternal wound infections after coronary artery bypass grafting by means of injection of platelet gel: an evolving technology. J Thorac Cardiovasc Surg 2010;139:e118-120.

[29] Cieslik-Bielecka A, Gazdzik TS, Bielecki TM, Cieslik T. Why the platelet-rich gel has antimicrobial activity? Oral Surg Oral Med Oral Pathol Oral Radiol Endod 2007;103:303-305.

[30] Bielecki TM, Gazdzik TS, Arendt J, Szczepanski T, Krol W, Wielkoszynski T. Antibacterial effect of autologous platelet gel enriched with growth factors and other active 
substances: an in vitro study. J Bone Joint Surg Br 2007;89:417-420.

[31] Moojen DJ, Everts PA, Schure RM, Overdevest EP, van Zundert A, Knape JT, Castelein RM, Creemers LB, Dhert WJ. Antimicrobial activity of platelet-leukocyte gel against Staphylococcus aureus. J Orthop Res 2008;26:404-410.

[32] Yang Y, Liu H, Liu G, Ran X. Antibacterial effect of autologous platelet-rich gel derived from health volunteers in vitro. Zhongguo Xiu Fu Chong Jian Wai Ke Za Zhi 2010;24:571-576. [33] Álvarez ME, López C, Giraldo CE, Samudio I, Carmona JU. In vitro bactericidal activity of equine platelet concentrates, platelet poor plasma, and plasma against methicillin-resistant Staphylococcus aureus. Arch Med Vet 2011;43:155-161.

[34] Tohidnezhad M, Varoga D, Podschun R, Wruck CJ, Seekamp A, Brandenburg LO, Pufe T, Lippross S. Thrombocytes are effectors of the innate immune system releasing human beta defensin-3. Injury 2011;42:682-686.

[35] Tohidnezhad M, Varoga D, Wruck CJ, Podschun R, Sachweh BH, Bornemann J, Bovi M, Sönmez TT, Slowik A, Houben A, Seekamp A, Brandenburg LO, Pufe T, Lippross S. Platelets display potent antimicrobial activity and release human beta-defensin 2. Platelets 2012;23:217223.

[36] Wu X, Ren J, Yuan Y, Luan J, Yao G, Li J. Antimicrobial properties of single-donorderived,platelet-leukocyte fibrin for fistula occlusion: An in vitro study. Platelets 2013;24:632636.

[37] Rozalski MI, Micota B, Paszkiewicz M, Wieckowoska-Szakiel M, Rozalska B. Antimicrobial/anti-biofilm activity of expired blood platelets and their released products. Postepy Hig Med Dosw 2013;67:321-325.

[38] $\mathrm{Li} \mathrm{H}, \mathrm{Li} \mathrm{B}$. PRP as a new approach to prevent infection: preparation and in vitro antimicrobial properties of PRP. J Vis Exp 2013;74. doi: 10.3791/50351.

[39] Drago L, Bortolin M, Vassena C, Taschieri S, Del Fabbro M. Antimicrobial activity of pure platelet-rich plasma against microorganisms isolated from oral cavity. BMC Microbiol 
2013;13:47. doi: 10.1186/1471-2180-13-47.

[40] Aktan I, Dunkel B, Cunningham FM. Equine platelets inhibit Escherichia coli growth and can be activated by bacterial lipopolysaccharide and lipoteichoic acid although superoxide anion production does not occur and platelet activation is not associated with enhanced production by neutrophils. Vet Immunol Immunopathol 2013;152:209-217.

[41] Burnouf T, Chou ML, Wu YW, Su CY, Lee LW. Antimicrobial activity of platelet (PLT)poor plasma, PLT-rich plasma, PLT gel, and solvent/detergent-treated PLT lysate biomaterials against wound bacteria. Transfusion 2013;53:138-146.

[42] Chen L, Wang C, Liu H, Liu G, Ran X. Antibacterial effect of autologous platelet-rich gel derived from subjects with diabetic dermal ulcers in vitro. J Diabetes Res 2013;2013:269527. doi: $10.1155 / 2013 / 269527$.

[43] Edelblute CM, Donate AL, Hargrave BY, Heller LC. Human platelet gel supernatant inactivates opportunistic wound pathogens on skin. Platelets 2015;26:13-16.

[44] Intravia J, Allen DA, Durant TJ, McCarthy MB, Russell R, Beitzel K, Cote MP, Dias F, Mazzocca AD. In vitro evaluation of the anti-bacterial effect of two preparations of platelet rich plasma compared with cefazolin and whole blood. Muscles Ligaments Tendons J 2014;4:79-84. [45] Mariani E, Filardo G, Canella V, Berlingeri A, Bielli A, Cattini L, Landini MP, Kon E, Marcacci M, Facchini A. Platelet-rich plasma affects bacterial growth in vitro. Cytotherapy 2014;16:1294-1304.

[46] Drago L, Bortolin M, Vassena C, Romanò CL, Taschieri S, Del Fabbro M. Plasma components and platelet activation are essential for the antimicrobial properties of autologous platelet-rich plasma: an in vitro study. PLoS One 2014;9(9):e107813. doi: 10.1371/journal.pone.0107813.

[47] Yang LC, Hu SW, Yan M, Yang JJ, Tsou SH, Lin YY. Antimicrobial activity of plateletrich plasma and other plasma preparations against periodontal pathogens. J Periodontol 2015;86:310-318. 
[48] Jia W, Zhang C, Wang J, Chen J, Jiang Y. An experimental study on antimicrobial efficacy of platelet-rich plasma for bone infection prophylaxis. Zhongguo Xiu Fu Chong Jian Wai Ke Za Zhi 2010;24:864-870.

[49] Jia WT, Zhang CQ, Wang JQ, Feng Y, Ai ZS. The prophylactic effects of plateletleucocyte gel in osteomyelitis: an experimental study in a rabbit model. J Bone Joint Surg Br 2010;92:304-310

[50] Li H, Hamza T, Tidwell JE, Clovis N, Li B. Unique Antimicrobial Effects of Platelet-Rich Plasma and Its Efficacy as a Prophylaxis to Prevent Implant-Associated Spinal Infection. Adv Healthc Mater 2013;2:1277-1284.

[51] Li GY, Yin JM, Ding H, Jia WT, Zhang CQ. Efficacy of leukocyte- and platelet-rich plasma gel (L-PRP gel) in treating osteomyelitis in a rabbit model. J Orthop Res 2013;31:949956.

[52] Mariani E, Canella V, Berlingeri A, Cattini L, Landini MP, Kon E, Marcacci M, Di Matteo B, Filardo G. Leukocyte presence does not increase microbicidal activity of Platelet-rich Plasma in vitro. BMC Microbiology 2015;15:149.

[53] Yuan T, Zhang CQ, Zeng BF. Treatment of chronic femoral osteomyelitis with platelet-rich plasma (PRP): A case report. Transfus Apher Sci 2008;38:167-170.

[54] Fodor, J. Die Fahigkeit des Blutes. Bakterien zu vernichten. Dtsch. Med. Wochenschr $1887 ; 13: 745-747$.

[55] Kerrigan SW. The expanding field of platelet-bacterial interconnections. Platelets $2015 ; 26: 293-301$

[56] Shannon O. Platelet interaction with bacterial toxins and secreted products. Platelets 2015;26:302-308.

[57] McNicol A. Bacteria-induced intracellular signaling in platelets. Platelets 2015;26:309-316. [58] Lu HJ, Chen TL, Zhang XH, Liu J, Bao HW. Antibacterial effects of platelet-rich plasma in promoting tacial scars healing in combination with adipose-derived stromal vascular fraction 


1
2
3
4
5
6
7
8
9
10
11
12
13
14
15
16
17
18
19
20
21
22
23
24
25
26
27
28
29
30
31
32
33
34
35
36
37
38
39
40
41
42
43
44
59
45
46
47
48
49
50
51
52
54
56

cells. J Craniofac Surg 2015. 


\section{Figure legends}

Figure 1. Flowchart summarizing the article selection process.

Figure 2. Risk-of-bias graph: judgments of review authors about each risk-of-bias item presented as percentages across all included studies for in vitro (a) and animal (b) studies. 
Table I. Characteristics of the in vitro studies assessing the antimicrobial effect of platelet concentrates.

\begin{tabular}{|c|c|c|c|c|c|c|}
\hline \multirow[b]{2}{*}{ Authors, year } & \multicolumn{4}{|c|}{ Platelet concentrate features } & \multirow[b]{2}{*}{ Microorganisms tested } & \multirow[b]{2}{*}{ Results } \\
\hline & Type & $\begin{array}{c}\text { Platelet } \\
\text { concentration } \\
\left(10^{3} / \mu \mathrm{l}\right) \text { mean } \\
\text { value } \pm \text { st.dev. }\end{array}$ & Activator(s) & $\begin{array}{c}\text { Leucocytes } \\
\text { content } \\
\left(10^{3} / \mu \mathrm{l}\right)\end{array}$ & & \\
\hline Mariani et al., 2015 [52] & $\begin{array}{l}\text { P-PRP/ } \\
\text { L-PRP }\end{array}$ & $290 / 861$ & calcium chloride & $<0.2 / 5450$ & $\begin{array}{l}\text { E. coli, } P \text {. aeruginosa, } E \text {. } \\
\text { faecalis, } S \text {. aureus, } K \text {. } \\
\text { pneumoniae }\end{array}$ & $\begin{array}{l}\text { In vitro antibacterial activity } \\
\text { of both P-PRP and L-PRP. } \\
\text { Similar activity between the } \\
\text { two formulations. }\end{array}$ \\
\hline Yang et al., 2015 [47] & P-PRP & $1690 \pm 0.32$ & calcium chloride & $\begin{array}{c}\text { No } \\
(0.08 \pm 0.02)\end{array}$ & $\begin{array}{l}F . \text { nucleatum, } \\
P . \text { gingivalis, } \\
\text { A. actynomicetemcomitans }\end{array}$ & Bacterial growth inhibition \\
\hline Yang et al., 2010 [32] & L-PRP & n.r. & $\begin{array}{l}\text { bovine thrombin } \\
\text { and calcium } \\
\text { gluconate } \pm \\
\text { apocynin }\end{array}$ & Yes & $\begin{array}{l}\text { S. aureus, } \\
\text { E. coli, } \\
\text { P. aeruginosa }\end{array}$ & $\begin{array}{l}\text { Potential bacteriostatic } \\
\text { effect against } S . \text { aureus by } \\
\text { platelet mediating; } \\
\text { No antimicrobial activity } \\
\text { against all tested } \\
\text { microorganisms }\end{array}$ \\
\hline Wu et al., 2013 [36] & L-PRF & $150 \pm 113$ & thrombin & $\begin{array}{c}\text { Yes } \\
(1.18 \pm 0.17)\end{array}$ & $\begin{array}{l}\text { E. coli, } \\
\text { K. pneumoniae, } \\
P . \text { aeruginosa }\end{array}$ & $\begin{array}{l}\text { Remarkable antimicrobial } \\
\text { activity Gram-negative } \\
\text { bacteria relevant to fistula } \\
\text { colonization; } \\
\text { Platelets and leukocytes } \\
\text { may be important in } \\
\text { bacterial defense }\end{array}$ \\
\hline $\begin{array}{l}\text { Tohidnezhad et al., } 2012 \\
\text { [35] }\end{array}$ & P-PRP & 3800 & $\begin{array}{l}\text { bovine thrombin } \\
\text { and calcium } \\
\text { chloride }\end{array}$ & No & $\begin{array}{l}\text { E. coli, } \\
\text { B. megaterium, } \\
\text { P. aeruginosa, } \\
\text { E. faecalis, }\end{array}$ & $\begin{array}{l}\text { Antimicrobial action against } \\
\text { all tested microorganisms; } \\
\text { Initial infection prevention } \\
\text { against } E \text {. coli and } P \text {. }\end{array}$ \\
\hline
\end{tabular}




\begin{tabular}{|c|c|c|c|c|c|c|}
\hline & & & & & P. mirabilis & mirabilis \\
\hline $\begin{array}{l}\text { Tohidnezhad et al., } 2011 \\
\text { [34] }\end{array}$ & P-PRP & 3800 & $\begin{array}{l}\text { bovine thrombin } \\
\text { and calcium } \\
\text { chloride }\end{array}$ & No & $\begin{array}{l}\text { E. coli, } \\
\text { B. megaterium, } \\
\text { K. pneumoniae, } \\
\text { E. faecalis, } \\
\text { P. mirabilis }\end{array}$ & $\begin{array}{l}\text { Antimicrobial action against } \\
\text { all tested microorganisms; } \\
\text { Identification of a possible } \\
\text { first line defense in } \\
\text { contaminated wounds }\end{array}$ \\
\hline Rozalski et al., 2013 [37] & P-PRP & 100 & $\mathrm{ADP}$ & No & S. aureus & $\begin{array}{l}\text { Good antimicrobial activity } \\
\text { even after the medical } \\
\text { expiry date; } \\
\text { Bacterial resistance test as a } \\
\text { predictive indicator of } \\
\text { susceptibility to infection } \\
\text { treatment }\end{array}$ \\
\hline Moojen et al., 2008 [31] & L-PRP & $1688 \pm 318$ & bovine thrombin & $\begin{array}{c}\text { Yes } \\
(17.90 \pm \\
2.62) \\
\end{array}$ & S. aureus & $\begin{array}{l}\text { Antimicrobial activity } \\
\text { against } S \text {. aureus }\end{array}$ \\
\hline Mariani et al., 2014 [45] & P-PRP & 290 & calcium chloride & $\begin{array}{c}\text { No } \\
(<0.2)\end{array}$ & $\begin{array}{l}\text { S. aureus, } \\
\text { E. faecalis, } \\
\text { E. coli, } \\
\text { K. pneumoniae, } \\
\text { P. aeruginosa }\end{array}$ & $\begin{array}{l}\text { Bacterial growth inhibition; } \\
\text { Early protection against } \\
\text { bacterial contamination } \\
\text { during surgical } \\
\text { interventions }\end{array}$ \\
\hline $\mathrm{Li} \& \mathrm{Li}, 2013$ [38] & L-PRP & 2000 & $\begin{array}{l}\text { bovine thrombin } \\
\text { and calcium } \\
\text { chloride }\end{array}$ & Yes & $\begin{array}{l}\text { S. aureus, } \\
\text { N. gonorrhoeae, Group A } \\
\text { steptococccus }\end{array}$ & $\begin{array}{l}\text { Strong in vitro antibacterial } \\
\text { properties against all tested } \\
\text { bacteria; } \\
\text { Potential to prevent } \\
\text { infection and to reduce the } \\
\text { need for costly post- } \\
\text { operative treatment of } \\
\text { implant-associated } \\
\text { infections }\end{array}$ \\
\hline Intravia et al., 2014 [44] & $\begin{array}{l}\text { P-PRP/ } \\
\text { L-PRP }\end{array}$ & $\begin{array}{l}386 \pm 65.5 / \\
867 \pm 234.4\end{array}$ & n.r. & $\begin{array}{c}\text { No } \\
(0.62 \pm \\
0.265) \\
\end{array}$ & $\begin{array}{l}\text { S. aureus, } \\
\text { S. epidermidis, } \\
P . \text { acnes, }\end{array}$ & $\begin{array}{l}\text { Significant bacterial growth } \\
\text { decrease for all tested } \\
\text { microorganisms; }\end{array}$ \\
\hline
\end{tabular}




\begin{tabular}{|c|c|c|c|c|c|c|}
\hline & & & & $\begin{array}{c}\text { Yes } \\
(11.96 \pm \\
4.74)\end{array}$ & S. aureus & $\begin{array}{l}\text { No antibacterial activity } \\
\text { difference between the two } \\
\text { preparations }\end{array}$ \\
\hline Edelbute et al., 2014 [43] & P-PRP & $\geq 1200$ & $\begin{array}{l}\text { bovine thrombin } \\
\text { and calcium } \\
\text { chloride and pulsed } \\
\text { electric fields }\end{array}$ & No & $\begin{array}{l}\text { A. baumannii, } \\
\text { P. aeruginosa, } \\
\text { S. aureus }\end{array}$ & $\begin{array}{l}\text { Significant antibacterial } \\
\text { effect against all tested } \\
\text { microorganisms }\end{array}$ \\
\hline Drago et al., 2014 [46] & P-PRP & $\begin{array}{c}565 \text { (P-PRP) } \\
989 \text { (2x P-PRP) } \\
2034 \text { (4x P-PRP) }\end{array}$ & calcium chloride & $\begin{array}{l}\text { No } \\
(<1)\end{array}$ & $\begin{array}{l}\text { E. faecalis, } \\
\text { S. oralis, } \\
\text { S. agalactiae, } \\
\text { S. aureus }\end{array}$ & $\begin{array}{l}\text { Antimicrobial activity } \\
\text { against all tested } \\
\text { microorganisms }\end{array}$ \\
\hline Drago et al., 2013 [39] & P-PRP & 252 & calcium chloride & $\begin{array}{c}\text { No } \\
(0.34 \pm 0.27)\end{array}$ & $\begin{array}{l}\text { P. aeruginosa, } \\
\text { E. faecalis, } \\
\text { S. oralis, } \\
\text { S. agalactiae, } \\
\text { C. albicans }\end{array}$ & $\begin{array}{l}\text { Antimicrobial activity } \\
\text { against } E \text {. faecalis, } C \text {. } \\
\text { albicans, } S \text {. agalactiae and } \\
S . \text { oralis; } \\
\text { Useful substance against } \\
\text { postoperative infections }\end{array}$ \\
\hline Chen et al., 2013 [42] & L-PRP & $1968.8 \pm 874.58$ & $\begin{array}{l}\text { thrombin and } \\
\text { calcium gluconate }\end{array}$ & $\begin{array}{c}\text { Yes } \\
(5.75 \pm 1.46)\end{array}$ & $\begin{array}{l}\text { S. aureus, } \\
\text { E. coli, } \\
\text { P. aeruginosa }\end{array}$ & $\begin{array}{l}\text { Antibacterial activity } \\
\text { against } S \text {. aureus; } \\
\text { Synergistic antibacterial } \\
\text { effect of platelet concentrate } \\
\text { and antibiotic combination }\end{array}$ \\
\hline Burnouf et al., 2013 [41] & L-PRP & 1356 & calcium chloride & $\begin{array}{l}\text { Yes } \\
(4.80)\end{array}$ & $\begin{array}{l}\text { E. coli, } \\
\text { E. cloacae, } \\
\text { P. aeruginosa, } \\
\text { K. pneumoniae, } \\
\text { S. epidermidis, } \\
\text { S. aureus, } \\
\text { B. cereus, } \\
\text { B. subtilis } \\
\end{array}$ & $\begin{array}{l}\text { Antimicrobial activity only } \\
\text { against } E . \text { coli, } P \text {. } \\
\text { aeruginosa, } K \text {. pneumonia } \\
\text { and } S \text {. aureus }\end{array}$ \\
\hline Bielecki et al., 2007 [30] & L-PRP & $228 \pm 59$ & $\begin{array}{l}\text { bovine thrombin } \\
\text { and calcium } \\
\text { chloride solution }\end{array}$ & $\begin{array}{c}\text { Yes } \\
(6.68 \pm 2.20)\end{array}$ & $\begin{array}{l}\text { S. aureus, } \\
\text { E. coli, } \\
\text { K. pneumoniae, }\end{array}$ & $\begin{array}{l}S . \text { aureus and } E \text {. coli growth } \\
\text { inhibition; } \\
\text { No activity against } K \text {. }\end{array}$ \\
\hline
\end{tabular}




\begin{tabular}{|c|c|c|c|c|c|c|}
\hline & & & & & \begin{tabular}{|l|} 
E. faecalis, \\
P. aeruginosa
\end{tabular} & $\begin{array}{l}\text { pneumoniae, E. faecalis and } \\
\text { P. aeruginosa }\end{array}$ \\
\hline Anitua et al., 2012 [6] & $\begin{array}{l}\text { P-PRP } \\
\text { L-PRP }\end{array}$ & $\begin{array}{c}636 \pm 97 \\
467 \pm 62\end{array}$ & calcium chloride & $\begin{array}{c}\text { Negligible } \\
(0.22 \pm 0.13) \\
\text { Yes } \\
(21.42 \pm \\
8.02)\end{array}$ & $\begin{array}{l}\text { S. aureus, } \\
\text { S. epidermidis }\end{array}$ & $\begin{array}{l}\text { Antimicrobial action against } \\
\text { all tested microorganisms } \\
\text { during the first few hours; } \\
\text { Potentially useful substance } \\
\text { against postoperative } \\
\text { infections }\end{array}$ \\
\hline Alvarez et al., 2011 [33] & L-PRP & 512.9 & calcium gluconate & $\begin{array}{c}\text { Yes } \\
(10 \pm 4.98)\end{array}$ & S. aureus & $\begin{array}{l}\text { Antibacterial effect against } \\
\text { S. aureus }\end{array}$ \\
\hline Aktan et al., 2013 [40] & L-PRP & $12.5^{*}$ & $\begin{array}{l}\text { phorbol myristate } \\
\text { acetate (PMA) and } \\
\text { thrombin }\end{array}$ & Yes & E. coli & $\begin{array}{l}\text { Activated platelets inhibited } \\
\text { E. coli growth }\end{array}$ \\
\hline
\end{tabular}

*diluted for experimental use; n.r.= not reported 
Table II. Characteristics of the animal studies assessing the antimicrobial effect of platelet concentrates.

\begin{tabular}{|c|c|c|c|c|c|c|c|}
\hline \multirow[b]{2}{*}{ Authors, year } & \multicolumn{4}{|c|}{ Platelet concentrate } & \multirow[b]{2}{*}{$\begin{array}{c}\text { Microorganisms } \\
\text { tested }\end{array}$} & \multirow[b]{2}{*}{ Animal model } & \multirow[b]{2}{*}{ Results } \\
\hline & Type & $\begin{array}{c}\text { Platelet } \\
\text { concentration } \\
\left(10^{3} / \mu \mathrm{l}\right) \text { mean } \\
\text { value } \pm \text { st.dev } \\
\end{array}$ & Activator(s) & $\begin{array}{l}\text { Leucocytes } \\
\left(10^{3} / \mu \mathrm{l}\right)\end{array}$ & & & \\
\hline Li et al., 2013 [50] & L-PRP & $+\gamma$ & thrombin & $\begin{array}{c}\text { Yes } \\
(13.51 \pm \\
0.43)\end{array}$ & $\begin{array}{l}\text { S. aureus, } \\
\text { Group A } \\
\text { Streptococcus, } \\
\text { N. gonorrhoeae, } \\
\text { E. coli, } \\
\text { Pseudomonas }\end{array}$ & $\begin{array}{l}\text { Rabbit model of } \\
\text { implant- } \\
\text { associated } \\
\text { spinal infection }\end{array}$ & $\begin{array}{l}\text { PRP antimicrobial } \\
\text { properties both in vitro and } \\
\text { in vivo depend on thrombin } \\
\text { concentration; } \\
\text { Useful adjunct strategy } \\
\text { against postoperative } \\
\text { implant-associated } \\
\text { infections }\end{array}$ \\
\hline Li et al., 2013 [51] & L-PRP & $1561 \pm 702$ & $\begin{array}{l}\text { bovine } \\
\text { thrombin }\end{array}$ & $\begin{array}{c}\text { Yes } \\
(24.2 \pm 24.2)\end{array}$ & S. aureus & $\begin{array}{l}\text { Rabbit model of } \\
\text { osteomyelitis }\end{array}$ & $\begin{array}{l}\text { Antimicrobial efficacy in } \\
\text { vivo; } \\
\text { Favorable alternative for } \\
\text { the treatment of } \\
\text { osteomyelitis }\end{array}$ \\
\hline Jia et al., 2010 [48] & L-PRP & n.r. & $\begin{array}{l}\text { bovine } \\
\text { thrombin }\end{array}$ & Yes & S. aureus & $\begin{array}{l}\text { Rabbit model of } \\
\text { osteomyelitis }\end{array}$ & $\begin{array}{l}\text { Bacterial reproduction } \\
\text { inhibition in vitro; } \\
\text { Effective in vivo bone } \\
\text { infection prevention }\end{array}$ \\
\hline Jia et al., 2010 [49] & L-PRP & $2636 \pm 356$ & $\begin{array}{l}\text { bovine } \\
\text { thrombin }\end{array}$ & $\begin{array}{c}\text { Yes } \\
(48.3 \pm 4.3)\end{array}$ & S. aureus & $\begin{array}{l}\text { Rabbit model of } \\
\text { osteomyelitis }\end{array}$ & $\begin{array}{l}\text { Significant reduction in the } \\
\text { infection rate and the } \\
\text { number of viable bacteria; } \\
\text { Novel strategy to prevent } \\
\text { bone infection in humans }\end{array}$ \\
\hline
\end{tabular}

n.r. $=$ not reported 

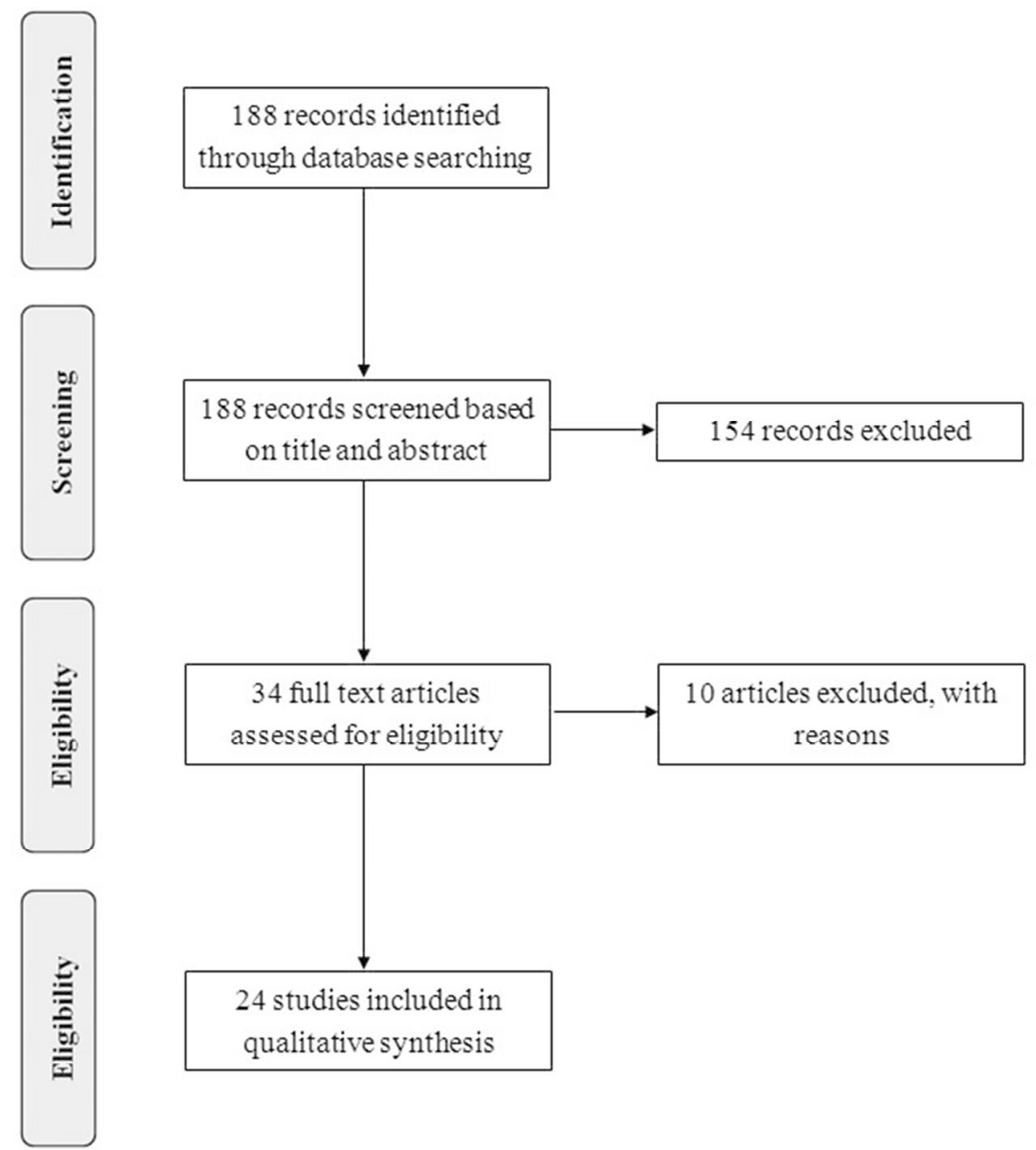

Figure 1. Flowchart summarizing the article selection process. $110 \times 123 \mathrm{~mm}(150 \times 150 \mathrm{DPI})$ 


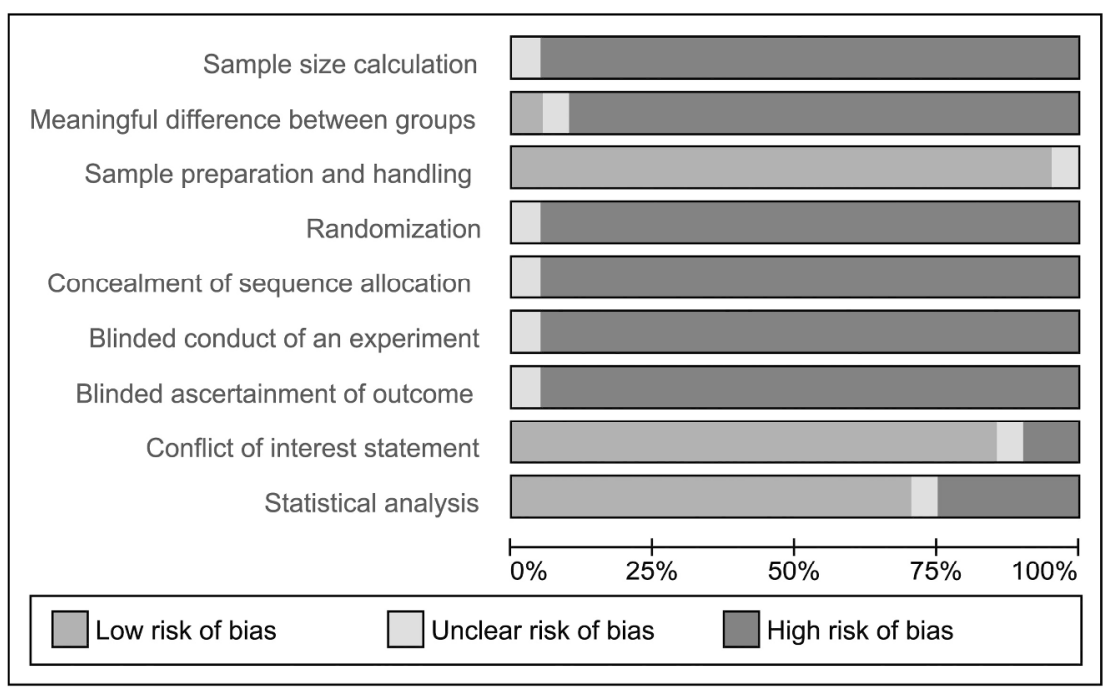

Figure 2. Risk-of-bias graph: judgments of review authors about each risk-of-bias item presented as percentages across all included studies for in vitro (a) and animal (b) studies. $215 \times 279 \mathrm{~mm}(300 \times 300 \mathrm{DPI})$ 


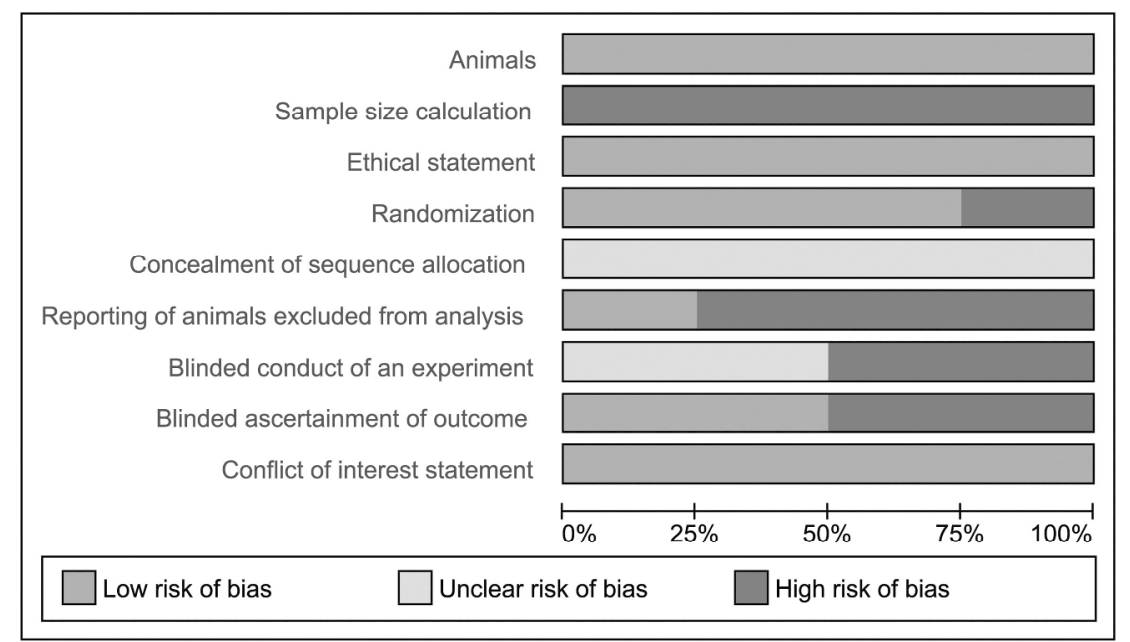

Risk-of-bias graph: judgments of review authors about each risk-of-bias item presented as percentages across all included studies for animal (b) studies $215 \times 279 \mathrm{~mm}(300 \times 300 \mathrm{DPI})$ 